\title{
[4+3]-Annulation of 3-Cyano-4-aryl-2-iminochromenes with 1,2- Diaminobenzene: An Access to Novel Chromenobenzodiazepines
}

\author{
Mohini Mourya ${ }^{a}$ \\ Himanshu Sharma \\ Yogesh C. Joshia \\ Ashok K. Basak*a,b (D) \\ a Department of Chemistry, University of Rajasthan, JLN Marg, \\ Jaipur-302004, India \\ akb31377@gmail.com \\ ${ }^{b}$ Department of Chemistry, Institute of Science, Banaras Hindu \\ University, Varanasi-221005, India
}
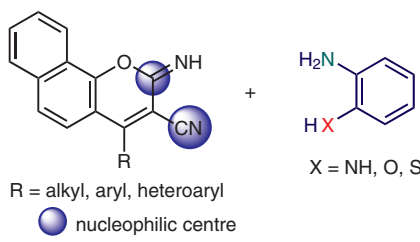

$\underset{100{ }^{\circ} \mathrm{C}}{\stackrel{\text { toluene-AcOH }}{\longrightarrow}}$

$\mathrm{X}=\mathrm{NH}, \mathrm{O}, \mathrm{S}$

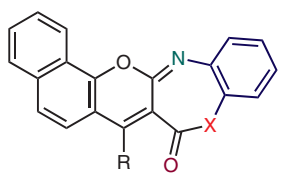

14 examples

upto $76 \%$ yields

new azepines/diazepines
Received: 26.02.2018

Accepted after revision: 05.04.2018

Published online: 08.05 .2018

DOI: 10.1055/s-0036-1591573; Art ID: so-2018-d0022-op

License terms: CCO

Abstract 3-Cyano-4-aryl-2-iminochromenes undergo [4+3]-annulation with 1,2-diaminobenzene under mild acidic conditions to generate novel chromenobenzodiazepines in good yields. The annulation reaction was also successful with 2-aminophenol and 2-aminothiophenol. The chromenobenzodiazepines could be conveniently reduced to the corresponding $4 \mathrm{H}$-chromenobenzodiazepines under mild acidic conditions.

Key words 3-cyano-4-aryl-2-iminochromene, 1,2-diaminobenzene, [4+3]-annulation, chromenobenzodiazepine, chromenobenzoazepine

Benzodiazepines have emerged as a 'privileged heterocyclic scaffold' in medicinal chemistry. ${ }^{1}$ More than 40 benzodiazepines have been commercialized as drugs and pharmaceuticals. A few biologically and medicinally important fused benzodiazepines are depicted in Figure 1. Benzodiazepines are known to possess anticancer, antioxidant, and antibacterial activities. ${ }^{2-5}$ Several benzodiazepine drugs greatly affect the central nervous system, especially in the brain and are used as antianxiety drugs. ${ }^{6}$ Benzodiazepines are believed to form a supramolecular complex with $\mathrm{GABA}_{\mathrm{A}}$ chloride ion channel, which modulates the action of gamma-aminobutyric acid on chloride ion flux.

2-Amino-3-cyano-4-aryl 4H-chromenes exhibit widespread biological profiles including anticancer, anti-HIV and antibacterial activities. ${ }^{7}$ Several $4 H$-chromene-derived heterocycles have also been found to possess important biological activities. For example, Kamal et al. generated chromenopyrimidine derivatives and showed that the compounds exhibit antitumor activities. ${ }^{8}$ Similarly, Proencą et al. reported the synthesis of fused chromenopyridines having antifungal activities. ${ }^{9}$ It has been observed that benzo- diazepines when fused with heterocyclic compounds exhibit superior activities. ${ }^{10}$ Recently, we reported the selective dehydrogenation of 2-amino-3-cyano-4-aryl $4 \mathrm{H}$ chromenes using diisopropyl azodicarboxylate in a polar aprotic solvent under neutral reaction conditions. ${ }^{11}$ The method provided easy access to 2-iminochromenes and thereby allowed us test their reactivity. Herein, we report an annulation reaction of 2-iminochromenes with 1,2-diaminobenzene to generate novel chromenobenzodiazepines in good yields (Scheme 1).<smiles>CN1C(=O)c2cnc(-c3ccccc3)nc2N(C(=O)CN2CCCCC2)c2ccccc21</smiles><smiles>OCCOCCN1CCN(C2=Nc3ccccc3Nc3ccccc32)CC1</smiles><smiles>Cc1nc(N(CO)CO)nc2c1C(=O)Nc1ccccc1N2</smiles><smiles>CN1c2ccccc2C(=O)n2c3ccccc3c3ccnc1c32</smiles><smiles>Cc1cc2c(s1)Nc1ccccc1N=C2N1CCN(C)CC1</smiles><smiles>O=C1Nc2c(Cl)ncnc2Nc2ccccc21</smiles>

Figure 1 A selection of biologically and medicinally important fused benzodiazepines

We hypothesized that the imino- and cyano groups of 2-iminochromene would be activated in the presence of an acid and behave as nucleophilic centers. This would create the opportunity for an annulation reaction with bidentate nucleophiles. With this aim, we screened several conditions for the annulation reaction of 2-iminochromene 1a with 1,2-diaminobenzene (2a). As shown in Table 1, the annulation reaction occurs under weakly acidic conditions. Condensation in acetic acid provided chromenobenzodiazepine 


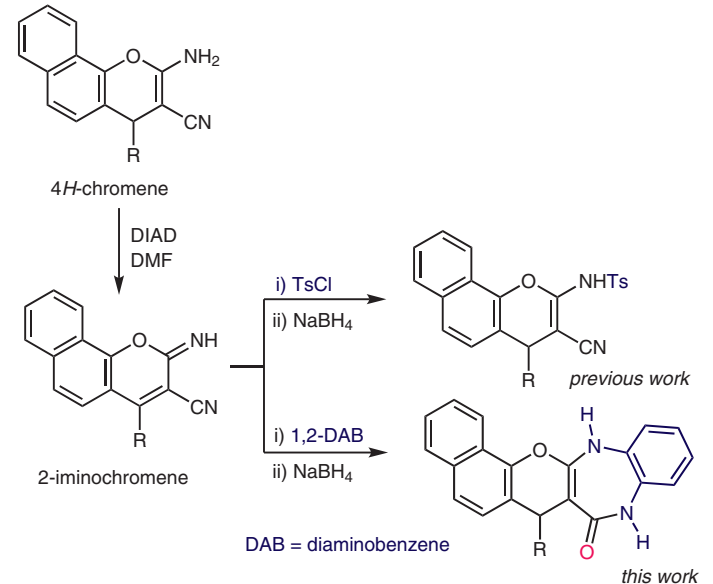

Scheme 1 Synthetic outline for chromenobenzodiazepine synthesis

3a in $55 \%$ yield (Table 1, entry 1). Reaction in pivalic acid and formic acid provided the benzodiazepine in low yields ( $46 \%$ and $42 \%$ yields, respectively). When TFA was used as a solvent, coumarin $\mathbf{4}$ was isolated as the predominant product. Condensations using mixed solvents were also tested and the results are presented in Table 1 (entries 5-9). In $\mathrm{EtOH}-\mathrm{AcOH}$ (9:1), the reaction generated chromenobenzodiazepine 3a in $40 \%$ yield. Reaction in DMF-AcOH (9:1) was rapid but generated unidentified polar compounds along with 3a (52\%). A low yield was observed when the condensation was carried out in dioxane-AcOH (9:1) mixture. However, an increase in isolated yield (64\%) was observed when the reaction was carried out in toluene-AcOH (9:1) mixture, and the best result was obtained using tolueneAcOH (4:1) (entry 9). No condensation reaction was observed in the absence of AcOH (entry 11).

The best conditions were then employed for the annulation reaction of several iminochromenes generated from chromenes via diisopropyl azodicarboxylate-mediated dehydrogenation. As shown in Figure 2, the condensation reactions usually generate chromenobenzodiazepines in good yields in short reaction times. Chromenobenzodiazepine $\mathbf{3 b}$, with a phenyl group at the 4-position, was obtained in $72 \%$ yield. Iminochromene, with a 3,4-dimethoxyphenyl group at the 4-position, generated the corresponding chromenobenzodiazepine $3 \mathrm{c}$ in $68 \%$ yields. When iminochromene having a $p$-nitrophenyl group at the 4-position was subjected to the annulation reaction, benzodiazepine 3d was obtained in $72 \%$ yield. The iminochromene with a cyclohexyl group at the 4-position also underwent smooth condensation reaction with 1,2-diaminobenzene to generate chromenobenzodiazepine $\mathbf{3 e}$ in $74 \%$ yield within three hours. The iminochromene containing a pyridyl group at the 4-position underwent effective condensation to furnish

Table 1 Optimization of Reaction Conditions for Annulation Reaction<smiles>COc1ccc(-c2c(C#N)c(=N)oc3c2ccc2ccccc23)cc1</smiles><smiles>Nc1ccccc1N</smiles>
$\underset{\text { conditions }}{\stackrel{\text { solvent }}{\longrightarrow}}$ 2a<smiles>COc1ccc(C2=C3C(=O)Nc4ccccc4N=C3Oc3c2ccc2ccccc32)cc1</smiles><smiles>COc1ccc(-c2c(C#N)c(=O)oc3c2ccc2ccccc23)cc1</smiles>

\begin{tabular}{|c|c|c|c|}
\hline Entry & Solvent & Conditions $^{\mathrm{a}}$ & Yield (\%) ${ }^{d}$ \\
\hline 1 & $\mathrm{AcOH}$ & $100^{\circ} \mathrm{C}, 4 \mathrm{~h}$ & 55 \\
\hline 2 & $\mathrm{Me}_{3} \mathrm{CCO}_{2} \mathrm{H}$ & $100^{\circ} \mathrm{C}, 4 \mathrm{~h}$ & 46 \\
\hline 3 & $\mathrm{HCOOH}$ & $100^{\circ} \mathrm{C}, 3 \mathrm{~h}$ & 42 \\
\hline 4 & TFA & $80^{\circ} \mathrm{C}, 1 \mathrm{~h}$ & ND \\
\hline 5 & EtOH-AcOH (9:1) & $80^{\circ} \mathrm{C}, 4 \mathrm{~h}$ & 40 \\
\hline 6 & DMF-AcOH (9:1) & $100{ }^{\circ} \mathrm{C}, 3 \mathrm{~h}$ & 52 \\
\hline 7 & dioxane-AcOH (9:1) & $100^{\circ} \mathrm{C}, 3 \mathrm{~h}$ & 42 \\
\hline 8 & toluene-AcOH (9:1) & $100^{\circ} \mathrm{C}, 3 \mathrm{~h}$ & 64 \\
\hline 9 & toluene-AcOH (4:1) & $100{ }^{\circ} \mathrm{C}, 2 \mathrm{~h}$ & 70 \\
\hline 10 & toluene- $\mathrm{PhCO}_{2} \mathrm{H}^{\mathrm{b}}$ & $100^{\circ} \mathrm{C}, 4 \mathrm{~h}$ & 48 \\
\hline 11 & toluene $^{c}$ & $100^{\circ} \mathrm{C}, 1 \mathrm{~h}$ & NR \\
\hline
\end{tabular}

${ }^{a}$ All reactions were carried out using iminochromene $1 \mathrm{a}$ (1.0 equiv), 1,2-diaminobenzene (1.0 equiv) in the appropriate solvent $(0.25 \mathrm{M})$

${ }^{b} \mathrm{PhCO}_{2} \mathrm{H}$ (10 equiv) was used.

c Reaction was carried out in the absence of $\mathrm{AcOH}$.

${ }^{\mathrm{N} D}$ = yield not determined; $\mathrm{NR}=$ no reaction. 
<smiles>COc1ccc(C2=C3C(=O)Nc4ccccc4N=C3Oc3c2ccc2ccccc32)cc1</smiles><smiles>O=C1Nc2ccccc2N=C2Oc3c(ccc4ccccc34)C(c3cccnc3)=C12</smiles>
$3 \mathrm{f}$
$2 \mathrm{~h}, 70 \%$<smiles>O=C1Oc2ccccc2N=C2Oc3c(ccc4ccccc34)C(c3ccc([N+](=O)[O-])cc3)=C1C2=O</smiles>

3k
$4 \mathrm{~h}, 61 \%$<smiles>O=c1[nH]c2c3c(c(=O)c1c1c(ccc4ccccc41)c3-c1ccccc1)Oc1ccccc1N=2</smiles>

3b
2 h, $72 \%$<smiles>O=C1Nc2ccccc2N=C2Oc3cc(O)ccc3C(c3cccnc3)=C1C2=O</smiles>

$3 \mathrm{~g}$<smiles></smiles>

31<smiles></smiles><smiles>O=c1[nH]c2c3c(-c4ccc([N+](=O)[O-])cc4)c4ccc5ccccc5c4c1c3Oc1ccccc1N=2</smiles><smiles>O=C1Nc2ccccc2N=C2Oc3c(ccc4ccccc34)C(C3CCCCC3)=C12</smiles>

3h, $74 \%$<smiles>COc1ccc(C2=C3C(=O)Oc4ccccc4N=C3Oc3c2ccc2ccccc32)cc1</smiles>

3i

3h

$6 \mathrm{~h}, 60 \%$

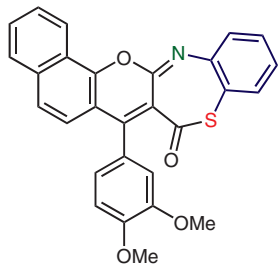

$3 \mathrm{~m}$
$5 \mathrm{~h}, 56 \%$

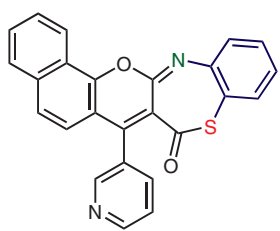

$3 n$
5 h, $74 \%$<smiles>COc1ccc(C2=C3C(=O)Oc4ccccc4N=C3Oc3c2ccc2ccccc32)cc1OC</smiles>

$6 \mathrm{~h}, 64 \%$

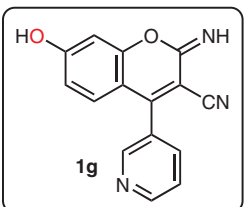

(Cll

Figure 2 [4+3]-Annulation of 2-iminochromenes with 1,2-diaminobenzene, 2-aminophenol and 2-aminothiophenol. All reactions were carried out using iminochromene $\mathbf{1}$ (1.0 equiv), $\mathbf{2}$ (1.0 equiv) in toluene- $\mathrm{AcOH}$ mixture (4:1, $0.25 \mathrm{M})$; $\mathrm{NR}=$ no reaction; $\mathrm{ND}=$ yield not determined.

chromenobenzodiazepine $\mathbf{3 f}$ in good yield (70\%). Iminochromene 1g, generated from the resorcinol-derived chromene, failed to undergo condensation to generate the chromenobenzodiazepine $\mathbf{3 g}$ the under the standard conditions. When the condensation reaction was carried out at higher temperature $\left(150^{\circ} \mathrm{C}\right)$, a complex reaction mixture was obtained. Similarly, iminochromene $\mathbf{1 h}$, generated from the resorcinol-derived chromene, also failed to give measurable amounts of compound $\mathbf{3 h}$. The successful annulations of iminochromenes generated from chromenes derived from $\alpha$-naphthol ${ }^{11}$ encouraged us to test the reaction with 2-aminophenol and 2-aminothiophenol under the standard conditions. To our satisfaction, annulation reactions with 2-aminophenol and 2-aminothiophenol were also effective and produced chromenobenzoazepines in moderate to good yields. These reactions usually required longer reaction time, presumably due to the lower nucleophilicity of the phenol and thiophenol groups. The iminochromene having a $p$-methoxyphenyl group at the 4-position required six hours for completion of condensation with 2 -aminophenol, producing chromenobenzoazepine $\mathbf{3 i}$ in moderate yield (60\%). The iminochromene possessing a 3,4dimethoxyphenyl group at the 4-position produced chromenobenzoazepine $\mathbf{3 j}$ in $64 \%$ yield. Chromenobenzoazepine 3k, having a $p$-nitrophenyl group at the 4-position, was obtained in $61 \%$ yield and iminochromene incorporating a 3pyridyl group at the 4-position also generated chromenobenzoazepine $\mathbf{3 1}$ in good yield (76\%). Annulation reactions of 2-aminothiophenols containing a 3,4-dimethoxyphenyl group and a 3-pyridyl group at the 4-position furnished the corresponding chromenobenzoazepines $\mathbf{3 m}$ and $\mathbf{3 n}$ in 56\% and $74 \%$ yields, respectively.

The mechanism of chromenobenzoazepine synthesis is depicted in Scheme 2. Concomitant nucleophilic addition of 1,2-diaminobenzene to the imino and cyano group of 2iminochromene $\mathbf{1}$ activated by the carboxylic acid via weak coordination generates intermediate $\mathbf{5}$, which liberates a molecule of ammonia to be converted into intermediate $\mathbf{6}$. Hydrolysis of the unstable intermediate $\mathbf{6}$ leads to the chromenobenzodiazepine $\mathbf{3}$ '. In case of resorcinol-derived iminochromenes $(\mathbf{1 g}, \mathbf{1 h})$, the phenolic hydroxyl group in- 

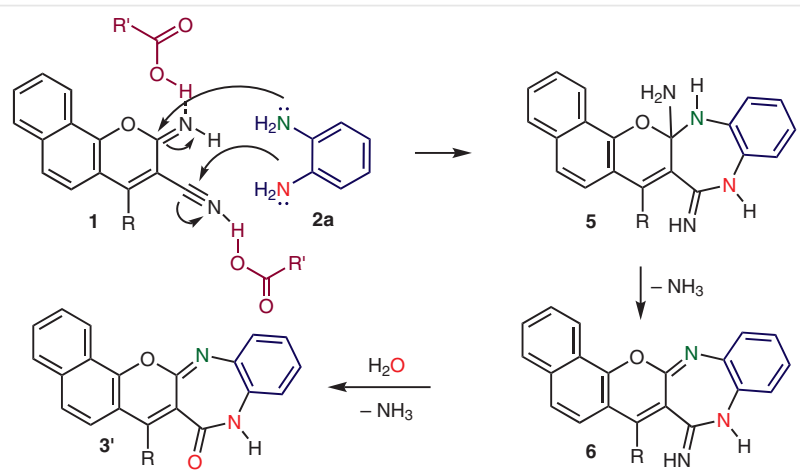

Scheme 2 Mechanism of chromenodiazepine synthesis

creases the electron density in the aromatic ring and presumably decreases the reactivity of the imino group towards nucleophiles.

Our efforts to convert the synthesized chromenobenzodiazepines into the corresponding $4 H$-chromenobenzodiazopines by reduction with $\mathrm{NaBH}_{4}$ met with difficulties. Reduction with $\mathrm{NaBH}_{4}$ in THF-MeOH $(4: 1)$ at $0{ }^{\circ} \mathrm{C}$ was not clean and generated several spots on TLC analysis. However, upon careful optimization, we were pleased to observe that addition of 10 equivalents of $\mathrm{AcOH}$ was necessary for clean reduction of the chromenobenzodiazepines to obtain $4 \mathrm{H}$ chromenobenzodiazopines in excellent yields (Scheme 3).
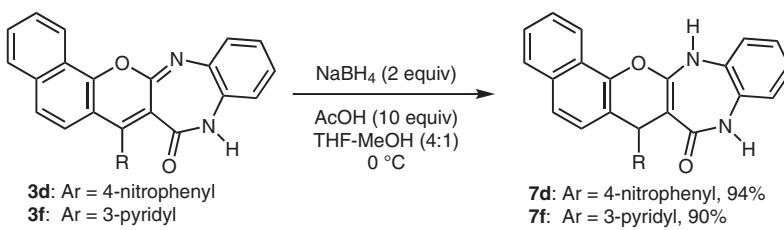

7d: $\mathrm{Ar}=4$-nitrophenyl, 94\% 7f: $\mathrm{Ar}=3$-pyridyl, $90 \%$

Scheme 3 Reduction of chromenobenzodiazepines

In summary, a general method for annulation of 2-iminochromenes with 1,2-diaminobenzene, 2-aminophenol and 2-aminothiophenol has been developed to generate biologically important 1,4-chromenobenzodiazepines and chromenobenzoazepines in good yields. The chromenobenzodiazepines can be conveniently reduced to the corresponding $4 \mathrm{H}$-chromenobenzodiazepines in the presence of $\mathrm{AcOH}$. The reduced $4 \mathrm{H}$-chromenobenzodiazepines offer opportunity for further structural elaboration.

Chemicals received from commercial sources were used without purification. The 2-iminochromenes were synthesized by following a reported procedure. ${ }^{11}$ All commercial grade solvents were used without purification. Column chromatography was performed on 60-120 mesh silica gel using a gradient mixture of EtOAc in petroleum ether (60$80^{\circ} \mathrm{C}$ ) as eluent. Mass spectra were recorded with a Waters Xevo G2-SQ TOF mass spectrometer. ${ }^{1} \mathrm{H}$ and ${ }^{13} \mathrm{C}$ NMR spectra were recorded with a Jeol JNM-ECS spectrometer at op- erating frequencies of $400 \mathrm{MHz}\left({ }^{1} \mathrm{H}\right)$ or $100 \mathrm{MHz}\left({ }^{13} \mathrm{C}\right)$, as indicated in the individual spectrum, using TMS as an internal standard. Multiplicities in the ${ }^{1} \mathrm{H}$ NMR spectra are presented as s for singlet, $\mathrm{d}$ for doublet, dd for doublet of doublet, $\mathrm{t}$ for triplet, and $\mathrm{m}$ for multiplet. Thin-layer chromatography was performed on aluminum plates (silica gel $60 \mathrm{PF}_{254}, 0.25 \mathrm{~mm}$ ) purchased from Merck.

\section{Typical Procedure}

A mixture of 3-cyano-4-( $p$-methoxyphenyl) 2-iminochromene 1a (200 mg, $0.61 \mathrm{mmol}$ ) and 1,2-diaminobenzene ( $66 \mathrm{mg}, 0.61 \mathrm{mmol}$ ) in toluene-AcOH $(4: 1,2.5 \mathrm{~mL})$ was stirred in a pre-heated oil bath at $100{ }^{\circ} \mathrm{C}$ under a nitrogen atmosphere. After 2 hours, TLC analysis indicted complete consumption of starting material. The reaction mixture was cooled to r.t. and solvent was evaporated under reduced pressure. The crude product was purified by silica gel column chromatography using a gradient mixture of $10 \rightarrow 30 \%$ EtOAc in hexane as eluent to obtain 3a (180 mg, 70\%) as a pale-yellow solid.

7-(4-Methoxyphenyl)benzo[b]benzo[7,8]chromeno[2,3-e][1,4]diazepin-8(9H)-one (3a)

Yield: $180 \mathrm{mg}$ (70\%); pale-yellow solid; $\mathrm{mp} 220-222^{\circ} \mathrm{C}$.

${ }^{1} \mathrm{H}$ NMR (DMSO- $\left.d_{6}, 400 \mathrm{MHz}\right): \delta=12.49$ (br s, $\left.1 \mathrm{H}, \mathrm{NH}\right), 8.51-8.45(\mathrm{~m}$, $1 \mathrm{H}), 8.07-8.01(\mathrm{~m}, 1 \mathrm{H}), 7.81(\mathrm{~d}, J=8.6 \mathrm{~Hz}, 1 \mathrm{H}), 7.79-7.74(\mathrm{~m}, 2 \mathrm{H})$, $7.48(\mathrm{~d}, J=8.0 \mathrm{~Hz}, 1 \mathrm{H}), 7.44(\mathrm{~d}, J=7.8 \mathrm{~Hz}), 7.26(\mathrm{~d}, J=8.7 \mathrm{~Hz}, 2 \mathrm{H})$, $7.21(\mathrm{~d}, J=8.8 \mathrm{~Hz}, 1 \mathrm{H}), 7.17-7.05(\mathrm{~m}, 2 \mathrm{H}), 6.91(\mathrm{~d}, J=8.7 \mathrm{~Hz}, 2 \mathrm{H})$, $3.69(\mathrm{~s}, 3 \mathrm{H})$.

${ }^{13} \mathrm{C}$ NMR (DMSO- $\left.d_{6}, 100 \mathrm{MHz}\right): \delta=160.0,159.8,156.6,150.7,146.3$, 143.6, 135.2, 134.5, 130.7, 130.1, 128.6, 128.4, 126.1, 124.9, 123.6, 123.0, 122.7, 122.4, 121.8, 119.6, 117.9, 115.4, 114.2, 112.0, 55.6.

HRMS (ESI): $m / z[M+H]$ calcd for $\mathrm{C}_{27} \mathrm{H}_{19} \mathrm{~N}_{2} \mathrm{O}_{3}: 419.1396$; found: 419.1410 .

\section{7-(Pyridin-3-yl)-8H-benzo[b]benzo[7,8]chromeno[2,3-e][1,4]ox-} azepin-8-one (31)

Yield: $200 \mathrm{mg}$ (76\%); dark-brown solid; $\mathrm{mp} 198-200{ }^{\circ} \mathrm{C}$.

${ }^{1} \mathrm{H} \mathrm{NMR}\left(\mathrm{CDCl}_{3}, 400 \mathrm{MHz}\right): \delta=8.74-8.65(\mathrm{~m}, 2 \mathrm{H}), 8.62(\mathrm{~s}, 1 \mathrm{H}), 7.93-$ $7.87(\mathrm{~m}, 1 \mathrm{H}), 7.78-7.71(\mathrm{~m}, 3 \mathrm{H}), 7.69-7.63(\mathrm{~m}, 2 \mathrm{H}), 7.45-7.36(\mathrm{~m}$, $2 \mathrm{H}), 7.35-7.26(\mathrm{~m}, 2 \mathrm{H}), 7.16$ (d, $J=8.6 \mathrm{~Hz}, 1 \mathrm{H})$.

${ }^{13} \mathrm{C}$ NMR $\left(\mathrm{CDCl}_{3}, 100 \mathrm{MHz}\right): \delta=158.2,156.9,155.2,152.0,150.6$, $148.7,141.1,136.3,135.7,130.2,130.1,128.0,127.9,125.9,125.0$, 124.7, 123.3, 123.0, 122.4, 120.7, 115.3, 114.3, 110.9.

HRMS (ESI): $m / z[\mathrm{M}+\mathrm{H}]$ calcd for $\mathrm{C}_{25} \mathrm{H}_{15} \mathrm{~N}_{2} \mathrm{O}_{3}$ : 391.1083; found: 391.1141.

\section{7-(Pyridin-3-yl)-9,14-dihydrobenzo[b]benzo[7,8]chromeno[2,3- e][1,4]diazepin-8(7H)-one (7f)}

Yield: $45 \mathrm{mg}$ (90\%); yellow solid; $\mathrm{mp} 235-236^{\circ} \mathrm{C}$.

${ }^{1} \mathrm{H}$ NMR (DMSO- $\left.d_{6}, 400 \mathrm{MHz}\right): \delta=10.25$ (br s, $\left.1 \mathrm{H}, \mathrm{NH}\right), 8.14$ (br s, $1 \mathrm{H}), 7.86(\mathrm{~d}, J=8.2 \mathrm{~Hz}), 7.71-7.54(\mathrm{~m}, 1 \mathrm{H}), 7.54-7.21(\mathrm{~m}, 7 \mathrm{H}), 7.18-$ $6.89(\mathrm{~m}, 4 \mathrm{H}), 6.11(\mathrm{~d}, J=11.8 \mathrm{~Hz}, 1 \mathrm{H}), 5.87(\mathrm{~d}, J=11.8 \mathrm{~Hz}, 1 \mathrm{H})$.

${ }^{13} \mathrm{C}$ NMR $\left(\mathrm{CDCl}_{3}, 100 \mathrm{MHz}\right): \delta=153.4,153.0,150.3,150.2,147.7$, 143.2, 142.6, 138.4, 136.0, 134.7, 133.5, 127.9, 126.3, 126.0, 125.5, 123.9, 123.7, 122.7, 121.9, 121.7, 120.2, 118.9, 118.7, 111.9, 44.5.

HRMS (ESI): $m / z[M+H]$ calcd for $\mathrm{C}_{25} \mathrm{H}_{18} \mathrm{~N}_{3} \mathrm{O}_{2}$ : 392.1399; found: 392.1405. 


\section{Funding Information}

A research grant from DST-SERB (YSS/2014/000957) and UGC (F.45/2006(BSR)), New Delhi is gratefully acknowledged.

\section{Acknowledgment}

M.M. and H.S. thank UGC, New Delhi for Research Fellowships. We thank MRC, MNIT Jaipur for NMR spectra. We are also grateful to USIC, University of Rajasthan for recording HRMS data.

\section{Supporting Information}

Supporting information for this article is available online at https://doi.org/10.1055/s-0036-1591573.

\section{References}

(1) Horton, D. A.; Bourne, G. T.; Smythe, M. L. Chem. Rev. 2003, 103, 893.

(2) Mohamed, M. S.; Awad, S. M.; Sayed, A. I. Molecules 2010, 15, 1882.

(3) Shireman, B. T.; Dvorak, C. A.; Rudolph, D. A. Bioorg. Med. Chem. Lett. 2008, 18, 2103.

(4) Shahidpour, S.; Panahi, F.; Yousefi, R.; Nourisefat, M.; Nabipoor, M.; Khalafi-Nezhad, A. Med. Chem. Res. 2015, 24, 3086.
(5) Gangjee, A.; Vidwans, A.; Elzein, E.; McGuire, J. J.; Queener, S. F.; Kisliuk, R. L. J. Med. Chem. 2001, 44, 1993.

(6) Maurizio, A.; Salvatore, V.; Carlo, B. J. Med. Chem. 2011, 54, 5694.

(7) (a) Kemnitzer, W.; Drewe, J.; Jiang, S.; Zhang, H.; CroganGrundy, C.; Labreque, D.; Bubenick, M.; Attardo, G.; Denis, R.; Lamothe, S.; Gourdeau, H.; Tseng, B.; Kasibhatla, S.; Cai, S. X. J. Med. Chem. 2008, 51, 417. (b) Kumar, D.; Reddy, B. V.; Sharad, S.; Dube, U.; Kapur, S. Eur. J. Med. Chem. 2009, 44, 3805. (c) Choi, M.; Hwang, Y.-S.; Kumar, A. S.; Jo, H.; Jeong, Y.; Oh, Y.; Lee, J.; Yun, J.; Kim, Y.; Han, S.-B.; Jung, J.-K.; Cho, J.; Lee, H. Bioorg. Med. Chem. Lett. 2014, 24, 2404. (d) Yin, S.-Q.; Shi, M.; Kong, T.-T.; Zhang, C.-M.; Han, K.; Cao, B.; Zhang, Z.; Du, X.; Tang, L.-Q.; Mao, X.; Liu, Z.-P. Bioorg. Med. Chem. Lett. 2013, 23, 3314. (e) Sabry, H. M.; Mohamed, H. M.; Khattab, E. S. A. E. H.; Motlaq, S. S.; ElAgrody, A. M. Eur. J. Med. Chem. 2011, 46, 765. (f) Roussaki, M.; Zelinanaois, K.; Kavetsou, E.; Hamilakis, S.; Hadjipavlou-Litina, D.; Kontogiorgis, Ch.; Liargkova, Th.; Delsi, A. Bioorg. Med. Chem. 2014, 22, 6586. (g) Balabani, A.; Hadjipavlou-Litina, D.; Litinas, K. E.; Mainou, M.; Tsironi, C.-C.; Vronteli, A. Eur. J. Med. Chem. 2011, 46, 5894. (h) Zhang, Y.; Zou, B.; Chen, Z. h.; Pan, Y.; Wang, H.; Liang, H.; Yi, X. Bioorg. Med. Chem. 2011, 21, 6811.

(8) Kandeel, M. M.; Kamal, A. M.; Abdelall, E. K. A.; Elshemy, H. A. H. Eur. J. Med. Chem. 2013, 59, 183.

(9) Costa, M.; Areias, F.; Abrunhosa, L.; Venâncio, A.; Proencą, F. J. Org. Chem. 2008, 73, 1954.

(10) Ambrogi, V.; Grandolini, G.; Perioli, L.; Giusti, L.; Lucacchini, A.; Martini, C. Eur. J. Med. Chem. 1995, 30, 429.

(11) Sharma, H.; Mourya, M.; Guin, D.; Joshi, Y. C.; Dobhal, M. P.; Basak, A. K. Tetrahedron Lett. 2017, 58, 1727. 